\title{
The effects of low-temperature storage on the viability of Lactobacillus case $i$ and the stability of antibacterial activity in green grass jelly synbiotic drinks
}

\author{
SAMSUL RIZAL ${ }^{1, \bullet}$, SUHARYONO $^{1}$, FIBRA NURAINY $^{1}$, JULFI RESTU AMELIA ${ }^{2}$ \\ ${ }^{1}$ Department of Agricultural Product Technology, Faculty of Agriculture, Universitas Lampung, Jl. Prof. Dr. Ir. Sumantri Brojonegoro No. 1, Bandar \\ Lampung 35145, Lampung, Indonesia. Tel.: +62-721-704946, Fax.: +62-721-770347, •email: samsul.rizal @ fp.unila.ac.id \\ ${ }^{2}$ Department of Agricultural Product Technology, Faculty of Agriculture, Universitas Sahid. Jl. Prof. DR. Soepomo, South Jakarta 12870, Jakarta, \\ Indonesia
}

Manuscript received: 7 June 2020. Revision accepted: 28 July 2020.

\begin{abstract}
Rizal S, Suharyono, Nurainy F, Amela JR. 2020. The effects of low-temperature storage on the viability of Lactobacillus casei and the stability of antibacterial activity in green grass jelly synbiotic drinks. Biodiversitas 21: 3826-3831. Synbiotic drinks from green grass jelly have shown antibacterial activity against pathogenic bacteria. These are usually stored at low temperatures to maintain their characteristics. The aim of this study was to determine the effect of storage at low temperature of $10^{\circ} \mathrm{C}$ on the viability of lactic acid bacteria (Lactobacillus casei) and the stability of the antibacterial activity in synbiotic drinks made of green grass jelly. Antibacterial activity of green grass jelly synbiotic drink was conducted against pathogenic bacteria (Staphylococcus aureus, Salmonella sp., Bacillus cereus, and Escherichia coli). The products were stored for 28 days at $10^{\circ} \mathrm{C}$ temperature. Observations on the antibacterial activity, $\mathrm{pH}$ value, total acid, and total lactic acid bacteria were carried out every 7 days. Antibacterial activity was evaluated using agar well diffusion method. The results showed that storage at low temperature $\left(10 \pm 2^{\circ} \mathrm{C}\right)$ for 28 days decreased the antibacterial activity and $\mathrm{pH}$ value but sharply increased total lactic acid bacteria (at 0 to 7 days of storage) in green grass jelly synbiotic drinks. Salmonella sp. showed the highest inhibition caused by the antibacterial agents in green grass jelly synbiotic drinks while the lowest inhibition was found on Staphylococcus aureus. During storage at low temperature, green grass jelly synbiotic drinks had a total of lactic acid bacteria that ranged from 9.51 to 10.10 (Log CFU/mL) or equal to $3.24 \times 10^{9}-1.26 \times 10^{10} \mathrm{CFU} / \mathrm{mL}$; a total of lactic acid that ranged from $0.48 \%$ to $0.87 \%$; and $\mathrm{pH}$ values that ranged from 3.78 to 4.08 .
\end{abstract}

Keywords: Antibacterial activity, green grass jelly, pathogenic bacteria, synbiotic

\section{INTRODUCTION}

The balance of microorganisms in human intestine could influence human health. An increase in the number of pathogenic bacteria in the human intestinal tract disturbs its balance; thus, the human body becomes less resistant to intestinal infection. Consuming drinks fermented by lactic acid bacteria is known to suppress the growth of pathogenic bacteria. These drinks mainly affect the development of microbiota that inhabits organisms by ensuring the right balance between pathogens and bacteria needed for the normal functioning of the organism (Oelschlaeger 2010). Another function of these drinks is to counteract the activity of pathogenic intestinal microbiota, which comes from contaminated food and environment (Markowiak and Slizewska 2017). Probiotic microbes work by the manipulation mechanism of the intestinal microbial community, suppression of pathogens, immunomodulation, and differentiation of epithelial cells and fortification of the intestinal barrier (Thomas and Versalovic 2010). The use of probiotics with the right dose is known to reduce and treat diarrhea (Aleta et al. 2020). In addition to probiotics, synbiotics also exhibit similar activity. Suharyono et al. (2012) and Rizal et al. (2019) proposed the idea of a green grass jelly drink fermented by lactic acid bacteria as a synbiotic drink.
Generally, synbiotic is defined as a mixture of probiotic and prebiotic. Probiotics are defined as live microorganisms that, when administered in adequate amounts, confer a health benefit on the host (Hill et al. 2014). Prebiotic is defined as non-digestible or lowdigestible food ingredients that benefit the host organism by selectively stimulating the growth or activity of limited number of probiotics in the colon (Manning and Gibson 2004). Green grass jelly (Premna oblongifolia Merr) is an Indonesian food plant with high dietary fiber content (Nurdin et al. 2017) and with potential to be prebiotic.

Green grass jelly synbiotic drink is a type of drink that contains lactic acid bacteria (Lactobacillus casei) as probiotics, green grass jelly powder as a prebiotic, and skim milk and glucose as sources of nutrients for the growth of lactic acid bacteria (Rizal et al. 2019). According to Rizal et al. (2019), this green grass jelly synbiotic drink contain antibacterial compounds, mainly lactic acid; thus, showed antibacterial activity against pathogenic bacteria, such as Staphylococcus aureus and Escherichia coli. To prevent changes in properties contained, fermented drinks should be kept in cold storage conditions at $10 \pm 2^{\circ} \mathrm{C}$. However, studies on the effect of storage at low temperature $\left(10 \pm 2^{\circ} \mathrm{C}\right)$ for green grass jelly synbiotic drinks on the viability of lactic bacteria and the stability of antibacterial activity are still limited. Research by 
Mirdalisa et al. (2016) showed that milk fermented by Lactobacillus casei showed a decrease in antimicrobial activity during storage at $5^{\circ} \mathrm{C}$ for up to 45 days. Qu et al. (2010) also found that at low temperatures, the antibacterial activity of silver nanoparticles (SNPs) get decreased. Therefore, this study aimed to determine the effect of lowtemperature storage on the viability of Lactobacillus casei and the stability of the antibacterial activity against pathogenic bacteria in green grass jelly synbiotic drinks.

\section{MATERIALS AND METHODS}

The main ingredients used in this study were grass jelly leaves from grass jelly plants (Premna oblongifolia Merr.), pure culture inoculums of lactic acid bacteria (Lactobacillus casei), pure culture of targeted bacteria (Salmonella sp., Staphylococcus aureus, Escherichia coli, and Bacillus cereus), skim milk, and sucrose. The chemicals used were citric acid, deMan-Rogosa, and Sharpe (MRS) Broth, deMan-Rogosa and Sharpe (MRS) Agar, Merck brand Nutrient Broth (NB), Nutrient Agar (NA) brand Oxoid, distilled water, $\mathrm{NaCl}(0.85 \%)$, alcohol, $\mathrm{NaOH}(0.1 \mathrm{~N})$, phenolphthalein indicator, and other analytical chemicals/ reagents.

The research was carried out in several stages. It started by making green grass jelly powder which was then extracted to be green grass jelly extract. The next step was to produce green grass jelly synbiotic drink by mixing green grass jelly extract, skim milk, glucose, and water in a container. It was then fermented with $L$. casei for 48 hours at $37^{\circ} \mathrm{C}$. The resulting green grass jelly synbiotic drinks were then stored at a low temperature of $10 \pm 2^{\circ} \mathrm{C}$ for 28 days with regular observation at every 7 days interval.

\section{Procedures}

Production of green grass jelly powder

Green grass jelly powder was produced according to a method developed by Nurdin et al. (2004). After discarding the damaged and unusable parts, green grass jelly leaves were washed firstly with running tap water to remove dust and other depositions on surface and then with sterilized distilled water 1-2 times. The cleaned green grass jelly leaves were slashed into small parts of $3 \times 1.5 \mathrm{~cm}^{2}$ and dehydrated in an oven at $50^{\circ} \mathrm{C}$ for 24 hours. The dehydrated leaves were then grounded with a blender, packed in a plastic bag, and stored at room temperature.

\section{Extraction of green grass jelly powder}

The extraction of green grass jelly powder was done according to a method developed by Nurdin et al. (2004). It started by adding 25 grams of green grass jelly powder into $500 \mathrm{~mL}$ of hot water $\left(100^{\circ} \mathrm{C}\right)$. To this $0.1 \%$ (w/v) of citric acid was added to prevent gel formation. It was then homogenized with stirrer "VWR Hot Plate" at full speed for 15 minutes. The mixture was strained to produce thick liquid of green grass jelly extract. This extract was poured into a large tray and dehydrated in an oven at $50^{\circ} \mathrm{C}$ for 48 hours. The resulting material was then grounded with a blender and strained through an 80-mash filter.

\section{Starter preparation}

The Lactobacillus casei starter culture was prepared using a method developed by Rizal et al. (2016). Pure culture of Lactobacillus casei in ampoules was transferred to an Erlenmeyer flask containing $50 \mathrm{~mL}$ of MRS broth and then incubated at $37^{\circ} \mathrm{C}$ for 48 hours. Two drops of the incubated broth were then inoculated into $10 \mathrm{~mL}$ solution of $10 \%(\mathrm{w} / \mathrm{v})$ skim milk that had been sterilized at $121^{\circ} \mathrm{C}$ for 15 minutes. After 48 hours of incubation at $37^{\circ} \mathrm{C}$, the mother culture was inoculated again in $0.5 \%(\mathrm{v} / \mathrm{v})$ into the same medium for another 48 hours at $37^{\circ} \mathrm{C}$ to obtain intermediate culture. As much as $0.5 \%(\mathrm{v} / \mathrm{v})$ of the intermediate culture was then inoculated into the same medium with the addition of $3 \%$ glucose for 24 hours at $37^{\circ} \mathrm{C}$. The resulting culture was used as starter for the production of green grass jelly synbiotic drinks.

\section{Production of green grass jelly synbiotic drinks}

Production of green grass jelly synbiotic drinks was done according to Nurdin et al. (2004) with a few modifications. It started by adding $2 \%(\mathrm{w} / \mathrm{v})$ of skim milk and $2 \%(\mathrm{w} / \mathrm{v})$ of glucose into an Erlenmeyer flask containing $100 \mathrm{~mL}$ of distilled water and $0.5 \%(\mathrm{w} / \mathrm{v})$ of green grass jelly extract. This mixture was homogenized using a stirrer for 2 minutes, then pasteurized at $80-85^{\circ} \mathrm{C}$ for 15 minutes. Finally, it was cooled down to $37^{\circ} \mathrm{C}$, inoculated with $4 \%(\mathrm{v} / \mathrm{v})$ of the Lactobacillus casei starter, and incubated at $37^{\circ} \mathrm{C}$ for 48 hours to produce green grass jelly synbiotic drinks. The drinks were then stored at a low temperature of $10 \pm 2{ }^{\circ} \mathrm{C}$ for 28 days. Antibacterial activity, total lactic acid bacteria, $\mathrm{pH}$ value, and total lactic acid of the products were evaluated at $0,7^{\text {th }}, 14^{\text {th }}, 21 \mathrm{st}$, and $28^{\text {th }}$ day of storage.

\section{Enumeration of lactic acid bacteria}

One milliliter of a sample of green grass jelly synbiotic drink was mixed with $9 \mathrm{ml}$ of a sterile physiological saline solution $(0.85 \% \mathrm{NaCl})$ in the initial dilution. For the calculation of the total amount of lactic acid bacteria $(L$. casei) present in the sample serial dilutions were made and $1 \mathrm{ml}$ of each of the two appropriate dilutions were mixed with melting media MRS (de Man-, Rogosa, and Sharpe) agar and the number of lactic acid bacteria was calculated using the pour-plate method (Yu et al. 2009). The media was incubated at $37^{\circ} \mathrm{C}$ for 48 hours

\section{Determination of $\mathrm{pH}$}

Determination of the $\mathrm{pH}$ value was done with an electronic $\mathrm{pH}$ meter. The tip of the indicator cathode of $\mathrm{pH}$ meter was washed with distilled water before use, and then cleaned with a soft tissue. Furthermore, the electronic $\mathrm{pH}$ meter was calibrated with the cathode tip dipped in buffer solutions 4 and 7 (Wahyudi 2006), then the cathode tip was dipped in a sample of green grass jelly synbiotic drinks. The measurement results are read on the $\mathrm{pH}$ meter.

\section{Titratable acidity determination (lactic acid)}

The amount of lactic acid produced in green grass jelly synbiotic drink was determined by a standard titration procedure for total titratable acidity (TTA) according to 
AOAC (1990). Determination of lactic acid levels was done by titrating $25 \mathrm{ml}$ of a sample of a synbiotic drink with the addition of 3 drops of phenolphthalein as an indicator. Sodium hydroxide $(\mathrm{NaOH}) \quad 0.1 \mathrm{M}$ was added slowly with tye help of burette into the sample until a pink color appeared. Every $\mathrm{ml}$ of $0.1 \mathrm{M} \mathrm{NaOH}$ was considered equivalent to $90.08 \mathrm{mg}$ of lactic acid.

Total titratable acidity of lactic acid $(\mathrm{mg} / \mathrm{ml})=$ $\underline{\mathrm{ml} \mathrm{NaOH} \times \mathrm{N} \mathrm{NaOH} \times \mathrm{M} . \mathrm{E}}$

Volume of sample used

Where, ml NaOH: Volume of $\mathrm{NaOH}$ used, $\mathrm{N} \mathrm{NaOH}$ : Molarity of $\mathrm{NaOH}$ used, M.E: Equivalent factor: $90.08 \mathrm{mg}$.

\section{Preparation of targeted cultures and evaluation of antibacterial activity}

Each targeted bacteria (Staphylococcus aureus, Salmonella sp., Bacillus cereus, and Escherichia coli) was transferred from stock culture into flasks containing $10 \mathrm{~mL}$ of Nutrient Broth and incubated for 24 hours at $37^{\circ} \mathrm{C}$. Each $20 \mu \mathrm{L}$ of the targeted culture was then seeded into Erlenmeyer flask containing $20 \mathrm{~mL}$ of sterilized Nutrient Agar, homogenized, poured onto a petri dish, and let solidify. Agar wells were created on the seeds using sterilized Agar Borer. Each $60 \mu \mathrm{L}$ of green grass jelly synbiotic drink was inoculated into the well. Antibacterial activity of green grass jelly synbiotic drinks was determined by agar well diffusion method (Murhadi 2002) with some modifications. Antibacterial activity was determined by the measurement of zone of inhibition (ZOI) around the wells after 24 hours of incubation at $37^{\circ} \mathrm{C}$. The diameter of the resulting zone was measured in millimeters. The experiment was performed in triplicates with every reading taken by two observers and the mean was calculated.

\section{RESULTS AND DISCUSSION}

\section{Total lactic acid bacteria (Lactobacillus casei)}

The results of present study showed that average total $L$. case $i$ in the product stored at low temperature $\left(10 \pm 2{ }^{\circ} \mathrm{C}\right)$ for $0,7,14,21$, and 28 days were $10.10,9.89,9.58,9.59$, and $9.51(\mathrm{Log} \mathrm{CFU} / \mathrm{mL})$ or equal with $1.26 \times 10^{10} \mathrm{CFU} / \mathrm{mL}$, $7.8 \times 10^{9} \mathrm{CFU} / \mathrm{mL}, 3.81 \times 10^{9} \mathrm{CFU} / \mathrm{mL}, 3.82 \times 10^{9} \mathrm{CFU} / \mathrm{mL}$, and $3.24 \times 10^{9} \mathrm{CFU} / \mathrm{mL}$, respectively (Figure 1). This indicated that total lactic acid bacteria in green grass jelly synbiotic drinks were relatively stable during storage at low temperature $\left(10 \pm 2{ }^{\circ} \mathrm{C}\right)$ for 28 days; which showed that storing green grass jelly synbiotic drinks at low temperature did not affect the viability of lactic acid bacteria in the drinks. This was relatively close to the results of a research carried out by Rizal (2009) which showed that storing of Turi milk yogurt at low temperature for 12 days had no significant effect on total lactic acid bacteria. In cold storage, lactic acid bacteria were alive but did not appear to perform significant metabolic activities. According to Pineiro and Stanton (2007), an important criterion for probiotics included that they should not only be able to survive through the digestive tract by showing tolerance of acid and bile, but also have the ability to multiply in the intestines. The ability of lactic acid bacteria to live in green grass jelly synbiotic drinks with low $\mathrm{pH}$ in cold conditions is important to its potential as a probiotic drink.

\section{Total lactic acid}

Lactic acid is the main compound resulted from a fermentation process involving lactic acid bacteria (Villalobos et al. 2020; Huang et al. 2020). As shown in Figure 2, total lactic acid in green grass jelly synbiotic drinks stored in a low temperature of $10 \pm 2{ }^{\circ} \mathrm{C}$ on day 0,7 , 14,21 , and 28 were $0.48 \%, 0.81 \%, 0.92 \%, 0.90 \%$, and $0.87 \%$ respectively.

It was observed that storage time in low temperatures increased total lactic acid in the product (Figure 2). There was a sharp increase in total lactic acid from $0.48 \%$ to 0.81 $\%$ at day 0 to day 7 . From day $7^{\text {th }}$ to day $28^{\text {th }}$, total lactic acid count increased gradually from $0.81 \%$ to $0.87 \%$ at the end of storage period. This result was accordance with the research results of Rizal et al. (2009) which revealed that storage at low temperature $\left(10 \pm 2{ }^{\circ} \mathrm{C}\right)$ for 12 days, the total lactic acid in Turi milk yogurt increased slightly from $0.73 \%$ on day 0 to $0.81 \%$ on day $12^{\text {th }}$.

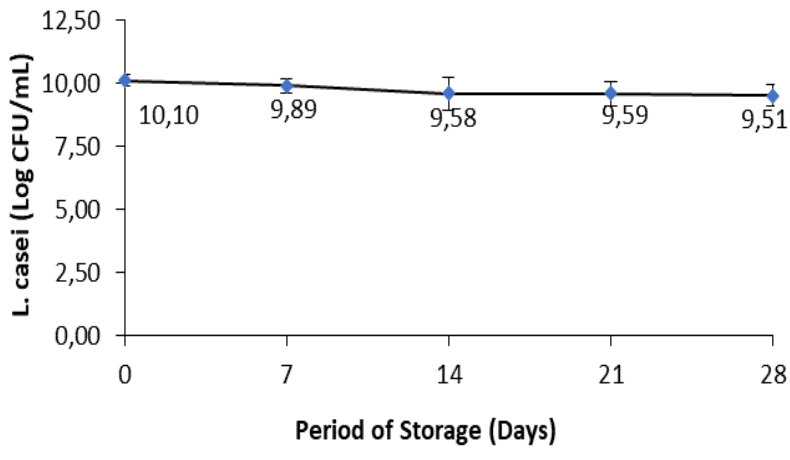

Figure 1. Total Lactobacillus casei in green grass jelly synbiotic drinks during storage in low temperature $\left(10 \pm 2^{\circ} \mathrm{C}\right)$

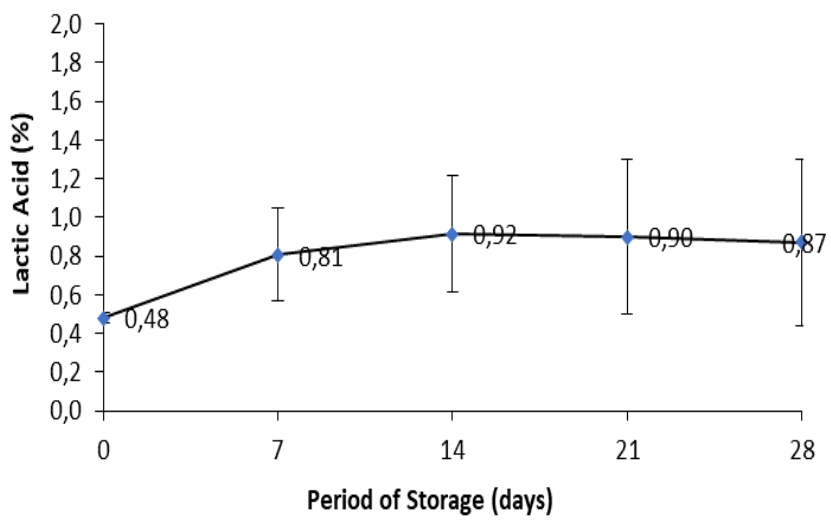

Figure 2. Total lactic acid in green grass jelly synbiotic drinks during storage in low temperature $\left(10 \pm 2^{\circ} \mathrm{C}\right)$ 
Nurainy et al. (2017) also stated that there was an increase in total lactic acid bacteria in a synbiotic guava juice for 28 days of cold storage. The total lactic acid from this study is also almost the same as the total of green grass jelly synbiotic by Putri et al. (2014), which ranges from $0.3-0.6 \%$. Higher lactic acid content of $1.5-4.5 \%$ was obtained in the study of Suharyono et al. (2012) from green grass jelly probiotic drinks

The increase of total lactic acid in green grass jelly synbiotic drinks during storage was caused by the production of lactic acid by lactic acid bacteria even though there was not a significant growth during that time. Charlier et al. (2009) stated that lactic acid was the main result of sugar metabolism by lactic acid bacteria. The presence of sucrose and skim milk in the product also caused an increase of total lactic acid. Abdel-Rahman et al. (2013) stated that carbohydrates were metabolized by lactic acid bacteria to produce lactic acid as their main metabolic end-product. Additionally, sucrose was used as an energy source for Lactobacillus casei to turn the lactose in skim milk into lactic acid.

\section{pH value (level of acidity)}

Acidity ( $\mathrm{pH}$ value) is an important indicator of the quality of fermented drinks as it is closely related to taste and texture (Li et al. 2017). Appropriate level of acidity gives the product a unique taste and inhibits the growth of pathogenic bacteria from food (Mufandaedza et al. 2006). As shown in Figure 3, the average $\mathrm{pH}$ value of green grass jelly synbiotic drinks stored at low temperatures $\left(10 \pm 2^{\circ} \mathrm{C}\right)$ on day $0,7,14,21$, dan 28 were $4.08,4.02,3.91,3.80$, and 3.78 respectively.

The $\mathrm{pH}$ value of green grass jelly synbiotic drinks during storage at low temperatures dropped slightly but was relatively stable (Figure 3). This indicated that storing green grass jelly synbiotic drink at a low temperature of 10 $\pm 2^{\circ} \mathrm{C}$ did not affect its $\mathrm{pH}$ value. Despite showing only slight changes, these $\mathrm{pH}$ values were low enough to inhibit the growth of preference bacteria. A slight decrease in $\mathrm{pH}$ was due to accumulation of lactic acid in the product from lactic acid bacteria metabolism. As stated by Huang (2020), the accumulation of lactic acid during fermentation of goat milk by the metabolism of lactic acid bacteria caused decrease in $\mathrm{pH}$ value while the acidity that could be titrated increases (Huang et al. 2020). Charlier et al. (2009) added that lactic acid bacteria are ubiquitous and heterogeneous species with a common feature of lactic acid production as the main result of sugar metabolism which leads to acidification of the environment up to $\mathrm{pH} 3.5$.

\section{Antibacterial activities}

Antibacterial activity of synbiotic green grass jelly drink was indicated by diameter of inhibition zone; the higher the diameter of the inhibition zone, higher was the antibacterial activity of the products. Antibacterial activity of green grass jelly synbiotic drinks against targeted pathogenic bacteria during storage at low temperatures (10 $\pm 2{ }^{\circ} \mathrm{C}$ ) is illustrated in Figure 4. According to Figure 4, the antibacterial activity of green grass jelly synbiotic drinks against all targeted bacteria decreased during $28^{\text {th }}$ days of storage at low temperatures $\left(10 \pm 2^{\circ} \mathrm{C}\right)$. These results were similar research carried out by Mirdalisa et al. (2016) which showed a decrease in antimicrobial activity of fermented milk during storage at low temperature of $5^{\circ} \mathrm{C}$ for 45 days. This decrease might be caused by the lack of growth in lactic acid bacteria during storage at low temperatures as shown in Figure 1. Sathe et al. (2007) evaluated that storage of Lactobacillus plantarum at $30^{\circ} \mathrm{C}$ showed maximum antimicrobial activity at the end of the exponential growth phase which then decreased in the stationary phase after 48 hours of growth.

Overall, the reduction in the diameter of the inhibition zones of all targeted bacteria indicated the decrease of antibacterial activities. Against Escherichia coli and Staphylococcus aureus, the antibacterial activities showed similarity and they were relatively stable throughout the storage period. Although, antibacterial activities against Salmonella sp. and Bacillus cereus were similar, but a significant decrease was observed. The diameter of Salmonella sp. inhibition zone decreased sharply from $22.67 \mathrm{~mm}$ at day 0 to $9.33 \mathrm{~mm}$ at $28^{\text {th }}$ day of storage, which amounted to $13.34 \mathrm{~mm}$ decrease.

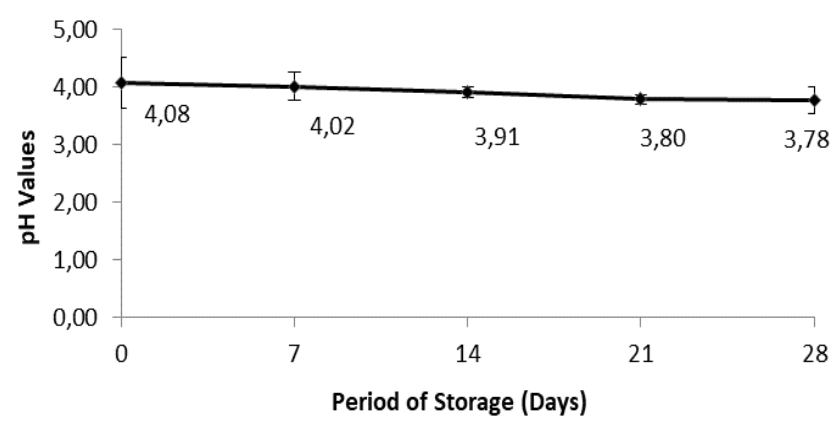

Figure 3. $\mathrm{pH}$ value of green grass jelly synbiotic drinks during storage in low temperature $\left(10 \pm 2^{\circ} \mathrm{C}\right)$

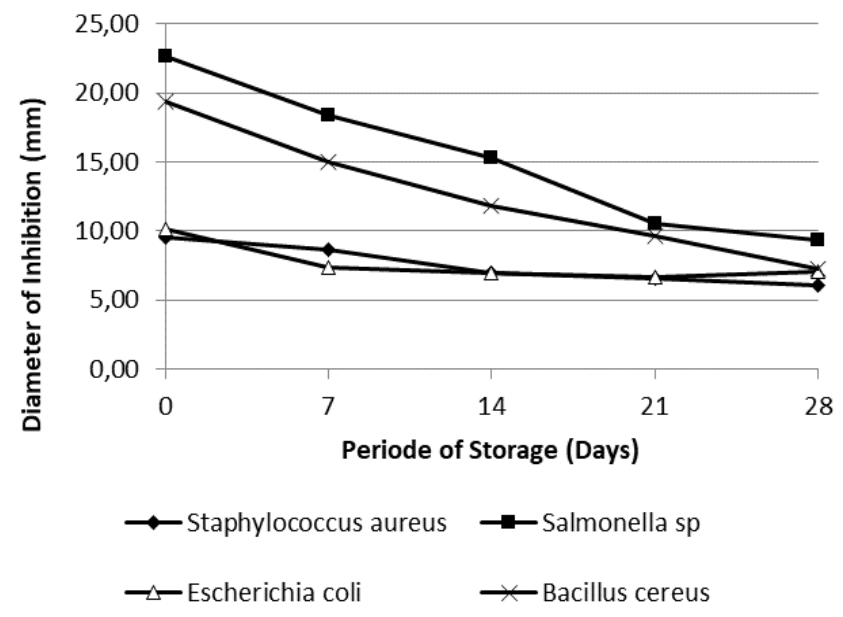

Figure 4. Antibacterial activities of green grass jelly synbiotic drinks against pathogenic bacteria during storage at low temperature $\left(10 \pm 2^{\circ} \mathrm{C}\right)$ 
The diameter of Bacillus cereus inhibition zone dropped significantly from $19.33 \mathrm{~mm}$ at day 0 to $7.22 \mathrm{~mm}$ at day $28^{\text {th }}$ which amounted to $12.11 \mathrm{~mm}$ decrease. However, the product still showed significant antibacterial activity as indicated by the diameter of the inhibition zone which still reaches $5 \mathrm{~mm}$. Rizal et al. (2016) stated that probiotic beverages from pineapple juice inhibited Streptococcus thermophylus with inhibition zone diameter $4.48 \mathrm{~mm}$. This inhibition zone diameter is wider than the inhibition zone diameter of the control (pineapple juice without fermentation) which was only $1.56 \mathrm{~mm}$. These results were in line with several researches that stated that probiotics might effectively inhibit the growth of pathogenic bacteria, such as Escherichia coli (Chingwaru and Vidmar 2017), Staphylococcus aureus (Sikorska and Smoragiewicz 2013), and Salmonella sp. (Carter et al. 2017). Liptáková et al. (2017) also stated that lactic acid bacteria and their metabolites were able to slow or inhibit the growth of undesirable bacteria. Due to these facts, probiotics had been proposed as preventative and therapeutic measures to restore the composition and function of healthy intestinal microbiomes (Hemarajata and Versalovic 2013).

A comparison of resistance of targeted bacteria against antibacterial agents in green grass jelly synbiotic drinks is presented in figure 4. According to this, Salmonella sp. was the most sensitive bacteria to the antibacterial activity of the green grass jelly synbiotic drinks, followed respectively by Bacillus cereus, Escherichia coli, and Staphylococcus aureus. The difference in antibacterial activity might be influenced by peptidoglycan in the cell walls of bacteria.

The ability of green grass jelly synbiotic drinks to suppress the growth of pathogenic bacteria may due to the presence of antimicrobial compounds produced by Lactobacillus casei (a kind of probiotic bacteria) during fermentation. According to Konuray and Erginkaya (2018), probiotic bacteria can produce bacteriocin, hydrogen peroxide, and organic acids such as lactic and acetic acid. Probiotics have many mechanisms to inhibit the growth of pathogenic microorganisms. These mechanisms lower the $\mathrm{pH}$ of the food mainly by producing lactic acid (Kalkan 2016). Lactic acid is an antimicrobial compound most likely present in green grass jelly synbiotic drinks as the final product of the fermentation process by lactic acid bacteria (Figure 2). These results are supported by the research of Rizal et al. (2019) which showed that green grass jelly synbiotic drinks supplemented with sucrose which can inhibit the growth of some food pathogens. In that study, green grass jelly synbiotic drinks produced total lactic acid which was almost the same as the results of this study, which ranged between 0.74 to $0.99 \%$. In other studies, antimicrobial activity against pathogenic bacteria has also been shown by similar products, namely probiotic drinks from pineapple skin, with lactic acid content reaching 1.95-3.45\% (Rizal et al. 2016).

In conclusion, total lactic acid bacteria, $\mathrm{pH}$, and antibacterial activity, in green grass jelly synbiotic drinks decreased gradually during storage at low temperatures $(10$ $\pm 2^{\circ} \mathrm{C}$ ) for 28 days, but the total lactic acid increased gradually. Among the targeted pathogenic bacteria, Salmonella sp. was the most sensitive against the antibacterial activity of green grass jelly synbiotic drinks, while Staphylococcus aureus was the most resistant one. Green grass jelly synbiotic drinks did not change significantly during storage at low temperatures $\left(10 \pm 2^{\circ} \mathrm{C}\right)$ for 28 days.

\section{REFERENCES}

Abdel-Rahman MA, Yukihiro Tashiro Y, Sonomoto K. 2013. Recent advances in lactic acid production by microbial fermentation processes. Biotechnol Adv 31: 877-902.

Aleta A, Hrvat F, Džuho A. 2020. Probiotics review and future aspects. Intl J Innov Sci Res Technol 5 (5): 270-274.

AOAC 1990. Association of Official Analytical Chemists. Official Methods of Analysis. 15th ed. AOAC, Arlington, VA.

Carter A, Adams M, La Ragione RM, Woodward, MJ. 2017. Colonisation of poultry by Salmonella enteritidis $\mathrm{S} 1400$ is reduced by combined administration of Lactobacillus salivarius 59 and Enterococcus faecium PXN-33. Vet Microbiol 199: 100-107.

Charlier C, Cretenet M, Even S, Le Loir, Y. 2009. Interactions between Staphylococcus aureus and lactic acid bacteria: an old story with new perspectives. Intl $\mathbf{J}$ Food Microbiol 131: 30-39. DOI: 10.1016/j.ijfoodmicro.2008.06032

Chingwaru W, Vidmar J. 2017. Potential of Zimbabwean commercial probiotic products and strains of Lactobacillus plantarum as prophylaxis and therapy against diarrhoea caused by Escherichia coli in children. Asian Pac J Trop Med 10: 57-63.

Hemarajata P, Versalovic J. 2013. Effects of probiotics on gut microbiota: mechanisms of intestinal immunomodulation and neuromodulation. Ther Adv Gastroenterol 6 (1): 39-51. DOI: 10.1177/ 1756283 X12459294.

Hill C, Guarner F, Reid G, Gibson GR, Merenstein DJ, Pot B. 2014. Expert consensus document: the international scientific association for probiotics and prebiotics consensus statement on the scope and appropriate use of the term probiotic. Nat Rev Gastroenterol Hepatol 11: $506-514$.

Huang Z, Huang L, Xing G, Xu X, Tu C, Dong M. 2020. Effect of cofermentation with lactic acid bacteria and $K$. marxianus on physicochemical and sensory properties of goat milk. Foods 9: 299. DOI: $10.3390 /$ foods9030299.

Kalkan S. 2016. Probiyotik laktik asit bakterilerinin Staphylococcus aureus a karşı antimikrobiyel etkilerinin farklı matematiksel modeller ile analizi. Sinop Uni J Nat Sci 1 (2): 150-159. \{Turkey]

Konuray G, Erginkaya Z. 2018. Antimicrobial Effect of Probiotics, Prebiotics, and Synbiotics. Antimicrobial research: Novel bio knowledge and educational programs (A. Mandez-Vilas,Ed)

Li C, Song J, Kwok LY, Wang J, Dong Y, Yu H, Chen Y. 2017. Influence of Lactobacillus plantarum on yogurt fermentation properties and subsequent changes during post-fermentation storage. J Dairy Science. 100: 2512-2525.

Liptáková D, Matejčeková Z, Valík L. 2015. Lactic Acid Bacteria and Fermentation of Cereals and Pseudocereals. Chapter 12. Intech, UK. DOI: $10.5772 / 65459$

Manning TS, Gibson GR. 2004. Prebiotics. Best Pract Res Clin Gastroenterol 18: 287-298.

Markowiak P, Slizewska K. 2017. Review: Effects of probiotics, prebiotics, and synbiotics on human health. Nutrients 9 (9): 1021.

Mirdalisa CA, Zakaria Y, Nurliana. 2016. Effects of temperature and storage time on the antimicrobial activity fermented milk with Lactobacillus casei. Agripet 16 (1): 49-55.

Mufandaedza J, Viljoen BC, Feresu SB, Gadaga TH. 2006. Antimicrobial properties of lactic acid bacteria and yeast-LAB cultures isolated from traditional fermented milk against pathogenic Escherichia coli and Salmonella enteritidis strains. Intl J Food Microbiol 108: 147-152

Murhadi. 2002. Isolasi dan Karakteristik Komponen Anti bakteri dari Biji Atung. [Dissertation]. Program Pascasarjana, Institut Pertanian Bogor, Bogor. [Indonesian].

Nurainy F, Rizal S, Suharyono, Destiyani N. 2017. Antibacterial activity and characteristics of green grass jelly extract with the addition of 
pineapple juice and guava during cold storage. Proceedings of the National Seminar on Western Region PTN BKS in Agriculture. Universitas Bangka Belitung, 20-21 Juli 2017 [Indonesian]

Nurdin SU, Richard K, Leu L, Young GP, Stangoulis JCR, Christophersen CT, Abbott CA. 2017. Analysis of the anti-cancer effects of cincau extract (Premna oblongifolia Merr) and other types of non-digestible fibre using faecal fermentation supernatants and $\mathrm{CaCo}-2$ cells as a model of the human colon. Nutrients 9 (4): 355.

Nurdin SU, Zuidar AS, Krisnawati R. 2004. Effect of citric acid concentration on the yield and properties of food fibers from leaves of grass jelly (Premna oblongifolia Merr). Proceedings of the National Seminar and Congress of the PATPI. Jakarta, 17-18 December 2004. [Indonesian].

Oelschlaeger TA. 2010. Mechanisms of probiotic actions-A mini-review. Intl J Med Microbiol 300: 57-62.

Pineiro M, Stanton C. 2007. Probiotic bacteria: legislative frameworkrequirements to evidence basis. J Nutr 137 (3): 850S-853S.

Putri A, Hanum T, Rizal S, Setyani S. 2014. Effects of glucose and orange juice (Citrus sinensis) addition on the characteristics of green cincau (Premna oblongifolia Merr.) synbiotic beverage. Jurnal Teknologi Industri dan Hasil Pertanian 19 (1): 104-116

Qu F, Xu H, Wei H, Lai W, Xiong Y, Xu F, Aguilar ZP, Xu H, Wang YA. 2010. Effects of $\mathrm{pH}$ and temperature on antibacterial activity of silver nanoparticles. Proceeding of 3rd International Conference on Biomedical Engineering and Informatics. AIP Conf Proc 1756: 080002. DOI: 10.1063/1.4958781.

Rizal S, Kustyawati ME, Nurainy F, Tambunan AR. 2016. Probiotic characteristic of lactic fermentation beverage of pineapple juice with variation of lactic acid bacteria (LAB) types. Indon J Applied Chem 18 (1): 63-72.
Rizal S, Suharyono, Amelia JR. 2019. The effect of addition of sucrose solution on the antibacterial activities of green grass jelly extracts synbiotic beverages during storage in cold temperature. Agriculture 31 (1): 53-66

Rizal S. 2009. Effect of CMC (Carboxymethyl cellulose) concentration on the stability and characteristics of turi milk yogurt during storage at cold temperatures. Proceedings of the National Seminar on Mathematics and Natural Sciences and their Applications.The University of Lampung. November 2009. [Indonesian]

Sathe SJ, Nawani NN, Dhakephalkar PK, Kapadnis BP. 2007. Antifungal lactic acid bacteria with potential to prolong self-life of fresh vegetables. J Appl Microbiol 103 (6): 2622-2628.

Sikorska H, Smoragiewicz W. 2013. Role of probiotics in the prevention and treatment of ethicillin-resistant Staphylococcus aureus infections. Intl J Antimicrob Agents 42: 475-481.

Suharyono, Rizal S, Nurainy F, Kurniadi M. 2012. Lactobacillus casei growth on various fermentation time synbiotic beverage of green grass jelly extract (Premna oblongifolia Merr). Jurnal Teknologi Hasil Pertanian 5 (2): 117-128.

Thomas C, Versalovic J. 2010. Probiotics-host communication: modulation of signaling pathways in the intestine. Gut Microbes 1: 148-163.

Villalobos JAM, Zamora JM, Barboza N, Garbanzo CR, Usaga J, Solano MR, Schroedter L, Widdrat AO, Gómez JPL. 2020. Multi-product lactic acid bacteria fermentations: A review. Fermentation 6 (23): 21.

Wahyudi, M. 2006. Proses pembuatan dan analisis mutu yoghurt. Buletin Teknik Pertanian. 11 (1): 12-16.

Yu J, Sun ZH, Liu WJ, Zhang JC, Sun TS, Bao QH, Zhang HP. 2009. Rapid identification of lactic acid bacteria isolated from home-made fermented milk in Tibet. J Gen Appl Microbiol 55: 181-190. 